Sains Malaysiana 50(10)(2021): 2977-2991

http://doi.org/10.17576/jsm-2021-5010-12

\title{
Sugar Recovery from Bakery Leftovers through Enzymatic Hydrolysis: Effect of Process Conditions and Product Characterization
}

(Perolehan Kembali Gula daripada Lebihan Bakeri melalui Hidrolisis Berenzim: Kesan Keadaan Proses dan Pencirian Produk)

\author{
Nurfatimah Mohd Thani, Siti Mazlina Mustapa Kamal*, Farah SaleEna Taip, Alifdalino Sulaiman \& \\ ROZITA OMAR
}

\section{ABSTRACT}

This study evaluates the process conditions, (enzyme concentration (120-1200 U/g substrate), temperature (30-60 $\left.{ }^{\circ} \mathrm{C}\right)$, and $\mathrm{pH}$ (3-9)) of enzymatic hydrolysis (EH) for sugar recovery from leftover croissants (LC) and leftover doughnut (LD), and characterizing its residue and hydrolysate. The highest sugar yield recovered from LC was $574.21 \pm 0.74 \mathrm{mg} / \mathrm{g}$ (840 U/g substrate, $49{ }^{\circ} \mathrm{C}$ and $\mathrm{pH} 3$ ) and for $\mathrm{LD}$ was $460.53 \pm 0.74 \mathrm{mg} / \mathrm{g}$ (1176 U/g substrate, $47{ }^{\circ} \mathrm{C}$ and $\mathrm{pH}$ 3). The highest fructose and glucose yield for LC and LD were $14.47 \pm 0.73 \mathrm{mg} / \mathrm{g}$ and $11.84 \pm 0.21 \mathrm{mg} / \mathrm{g}$, and $13.26 \pm 0.63 \mathrm{mg} / \mathrm{g}$ and $10.34 \pm 0.11 \mathrm{mg} / \mathrm{g}$, respectively. Morphology analysis (SEM) showed that the structure of LC and LD had changes in its starch granules that indicates hydrolysis process occurrence. The presence of monosaccharides and oligosaccharides were detected from FTIR. HMF was also detected from sugar degradation due to $\mathrm{EH},(0.043 \pm 0.0334 \mathrm{mg} / \mathrm{g}$ for LC) and $(0.023 \pm 0.0124 \mathrm{mg} / \mathrm{g}$ for $L D)$.

Keywords: Bakery leftovers; enzyme hydrolysis; glucose; hydroxymethylfurfural; sugar

\section{ABSTRAK}

Kajian ini menilai keadaan proses (enzim (120-1200 U/g substrat), suhu (30-60 ${ }^{\circ} \mathrm{C}$ ) dan pH (3-9)) hidrolisis berenzim untuk perolehan kembali gula daripada sisa kroisan dan sisa donat dan mencirikan hampas dan hidrolisatnya. Hasil gula tertinggi yang diperoleh daripada sisa kroisan adalah $574.21 \pm 0.74 \mathrm{mg} / \mathrm{g}\left(840 \mathrm{U} / \mathrm{g}\right.$ substrat, $49^{\circ} \mathrm{C}$ dan pH 3) dan untuk LD adalah $460.53 \pm 0.74 \mathrm{mg} / \mathrm{g}$ (1176 U/g substrat, $47{ }^{\circ} \mathrm{C}$ dan $\left.\mathrm{pH} 3\right)$. Hasil fruktosa dan glukosa tertinggi untuk sisa kroisan dan sisa donat masing-masing adalah $14.47 \pm 0.73 \mathrm{mg} / \mathrm{g}$ dan $11.84 \pm 0.21 \mathrm{mg} / \mathrm{g}$ dan $13.26 \pm 0.63 \mathrm{mg} / \mathrm{g}$ dan $10.34 \pm 0.11 \mathrm{mg} / \mathrm{g}$. Analisis morfologi (SEM) menunjukkan bahawa struktur sisa kroisan and sisa donat mempunyai perubahan pada butiran kanji yang menunjukkan berlakunya proses hidrolisis. Kehadiran monosakarida dan oligosakarida telah dikesan daripada FTIR. HMF juga telah dikesan daripada kemerosotan gula yang disebabkan oleh hidrolisis berenzim (0.043 $\pm 0.0334 \mathrm{mg} / \mathrm{g}$ untuk sisa kroisan) dan (0.023 $\pm 0.0124 \mathrm{mg} / \mathrm{g}$ untuk sisa donat).

Kata kunci: Glukosa; gula; hidroksimetilfurfural; hidrolisis berenzim; sisa roti

\section{INTRODUCTION}

Bakery waste that categorizes under cereal is among the most wasted food. As one of the staple food globally and the prime source of carbohydrate, it is a sad fact that the majority of bakery products wasted are still fresh, raw or minimally processed (Ventour 2008). According to Gustavsson et al. (2011), every year around the world, 1.3 billion tonnes of foods are wasted. Bakery waste is part of cereal food category, which this category accumulated approximately $30 \%$ of the total food waste in the world (FAO 2013). Bakery products' short shelf life and its sensitivity towards moisture in the environment have contributed to the increasing amount of bakery products being discarded, where it will be ended up in the landfill and/or turn into animal feed. Not only this situation may lead to landfill exhaustion, but the degradation of bakery wastes contributed to the increase of carbon dioxide $\left(\mathrm{CO}_{2}\right)$ and methane $\left(\mathrm{CH}_{4}\right)$ gas release, thus generating Green House Gas (GHG) emission. Other environmental impacts are water use and pollution of water, air and soil system (Moult et al. 2018).

However, to its richness in carbohydrate makes it a potential material to be converted into valuable products, 
particularly sugar which can be used as food ingredients raw materials in producing biofuel. Sánchez and Cardona (2008) have reviewed fuel ethanol production derived from assorted sugar-rich materials. The authors concluded that the starchy materials available in the present time can cater to market demands. Furthermore, the world could no longer rely on sugar cane as the prime source for sugar; due to limited land space, large scale farming as well as climate change that might affect the sugar production from sugar cane.

Bakery wastes can be a potential source for recovering the sugar through enzymatic hydrolysis (Mohd Thani et al. 2019). According to Akpinar et al. (2009), enzymatic hydrolysis is generally preferable in the food industry due to its simplicity and it will not produce undesirable by-products. Amezcua-Allieri et al. (2017), Demirci et al. (2017), Hudečková et al. (2017), Mahfuzul Islam et al. (2018), and Wang et al. (2011) displayed the potential of enzymatic hydrolysis process to produce sugar from different materials. Regardless of the advantages of enzymatic hydrolysis, to maximize the yield from this process as well as to bring it to a larger production scale, several factors need to be scrutinized and optimized. Some of the factors that important to enzymatic hydrolysis process are enzyme concentrations, process temperature, and $\mathrm{pH}$. The Response Surface Methodology (RSM) was selected for optimization analysis as RSM generated a mathematical model that accurately described the overall process with a significant ability for estimation (Wasswa et al. 2007). Some of the researchers that have employed RSM in their recent works are Fazil et al. (2018), Morais and Rodrigue (2018), Posridee et al. (2018), and Rasli and Sarbon (2018).

The aims of this research were to: study the effect of process conditions of enzymatic hydrolysis of LC and LD on the sugar yield, optimize the process conditions of enzymatic hydrolysis in order to obtain maximum sugar yield from LC and LD, and to analyze the morphology of the residue and it products after EH at optimal conditions in terms of its chemical composition, and quantification of its by-product; hydroxymethylfurfural (HMF) content).

\section{MATERIALS AND METHODS}

\section{SAMPLE PREPARATION}

For this study, croissants and doughnuts were chosen due to its famousness among consumers, whereby in Malaysia, majority of bakeries sell croissants and doughnuts in their outlets. Croissants and doughnuts were taken from a local bakery shop in Selangor, Malaysia. The samples were plain croissants and doughnuts without coating or filling. Prior to enzymatic hydrolysis, all the samples undergo yeast and mould analysis, where the results showed that all the samples were still in the admissible limit $(5 \times 103 \mathrm{CFU} / \mathrm{g})$, indicating that the products were in the acceptable and safe conditions to be consumed (Hozová et al. 2002). After that, leftover croissants (LC) and leftover doughnuts (LD) were crushed using a knife mill, vacuum packed and finally stored at $-20^{\circ} \mathrm{C}$ for later analysis. The other chemicals, solvents, and standard sugar all were analytical grades (Fisher Scientific, UK). From preliminary experiment, the carbohydrate content of leftovers croissants $(\sim 52 \%$ wet basis) was higher than leftovers doughnuts ( $47 \%$ wet basis) (Mohd Thani et al. 2020).

\section{ENZYMATIC HYDROLYSIS REACTION}

Amyloglucosidase produced from Aspergillus niger (Sigma 10113) was purchased from Megazymes. The enzyme unit is $120 \mathrm{U} / \mathrm{mg}$. For the enzymatic hydrolysis, $1.5 \mathrm{~g}$ of the substrate was mixed with $30 \mathrm{~mL}$ of distilled water in the Erlenmeyer Flask. The range of $\mathrm{pH}$ was from pH 3 until 9 for the slurry, and it was adjusted according to the experimental runs using $1 \mathrm{~mol} \mathrm{~L}^{-1} \mathrm{H}_{2} \mathrm{SO}_{4}$ or $\mathrm{NaOH}$ solutions. Different levels of enzyme concentrations (120-1200 U/g substrate). The selection range was based on previous studies that had used amyloglucosidase on carbohydrate-rich materials for enzymatic hydrolysis (Demirci et al. 2017; Han et al. 2016). The flasks were placed in the incubator shaker $(200 \mathrm{rpm})$ for $24 \mathrm{~h}$ at temperatures of $30-60{ }^{\circ} \mathrm{C}$. The enzymatic reaction was ended by heating the suspension at $80{ }^{\circ} \mathrm{C}$ for $5 \mathrm{~min}$. The mixture was immediately cooled and centrifuged at $9000 \mathrm{rpm}$ for $30 \mathrm{~min}$. The supernatant (hydrolysate) was filtered and collected for further analysis.

\section{TOTAL SUGAR YIELD ANALYSIS}

The determination of sugar yield in the hydrolysate was based on a method by Nielson (2010). $1 \mathrm{~mL}$ of $5 \%$ phenol solution, $5 \mathrm{~mL}$ of sulfuric acid $\left(\mathrm{H}_{2} \mathrm{SO}_{4}\right)$, and 1 $\mathrm{mL}$ of the hydrolysate were mixed well and vortexed for 5 minutes. By using Ultrospec 3100 Pro UV/visible spectrophotometer, the absorption of the solution was recorded at $490 \mathrm{~nm}$, in accordance with glucose as the standard. The total sugar yield was defined as in (1).

Total Sugar Yield $\left(\frac{\mathrm{mg}}{\mathrm{g}}\right)=\frac{\text { Weight of total sugar }(\mathrm{mg})}{\text { Weight of substrate }(\mathrm{g})}$ 


\section{SUGAR PROFILE ANALYSIS}

Hydrolysate obtained after enzymatic hydrolysis were analyzed for identification and quantification of the sugar using high-performance liquid chromatography (HPLC) (Jasco, Japan), consisted with an auto sampler, a column heater, and a pump. The column used was Agilex Hi-Plex $\mathrm{H}$ column $(300 \times 7.7 \mathrm{~mm})$, at $65^{\circ} \mathrm{C}$ with distilled water as the mobile phase. $20 \mu \mathrm{L}$ of the sample was injected at a flow rate of $0.3 \mathrm{~mL} / \mathrm{min}$. Quantification of sugar compounds was compared to calibration curves of glucose, fructose, mannose, galactose, and arabinose standards. The yield of monosaccharide was calculated using (2), where $\mathrm{M}_{\text {mono }}$ is concentration of monosaccharides, $\mathrm{V}_{\mathrm{aq}}$ is the volume of aqueous phase, and $\mathrm{W}_{\text {substrate }}$ is mass of substrate.

Yield of monosaccharides $(\mathrm{mg} / \mathrm{g}$ substrate $)=\frac{\mathrm{M}_{\mathrm{mono}}(\mathrm{mg} / \mathrm{L}) \times \mathrm{V}_{\mathrm{aq}}(\mathrm{L})}{\mathrm{W}_{\text {substrate }}(\mathrm{g})}$

\section{EXPERIMENTAL DESIGN AND ANALYSIS FOR OPTIMIZATION}

The response surface methodology (RSM) method was used to optimize and predict the optimum process condition. Prior to process conditions optimization, a onetime factor was carried out in very broad range, which to evaluate the effect of process conditions on hydrolysis processes. Based from the one-time factor results, three significant levels of each parameter were selected in order to obtain maximum (optimum) total sugar yield. The selected levels were then used to design the optimization stage using RSM.

A three-level three-factor face-centered central composite design (CCD) generated using Design Expert ${ }^{\circledR}$ software (Stat Ease Corp, USA) was employed to study the interaction of the independent variables; enzyme concentration (U/g substrate), process temperature $\left({ }^{\circ} \mathrm{C}\right)$ and $\mathrm{pH}$ on total sugar yield as the response from LC and LD. The independent variables were employed at three levels $(-1,0,1)$, whereby the range of enzyme concentration was selected at 840-1200 (U/g substrate), process temperature at $40-60^{\circ} \mathrm{C}$ and $\mathrm{pH}$ at 3-5.5. A total of 20 experimental runs were generated using CCD (Table 1 ), and the experimental runs were done in a randomized manner. The experimental results or response (total sugar yield) for each run are also presented in Table 1.

TABLE 1. Central composite design (CCD) values of enzymatic hydrolysis conditions, and result data for leftover croissants (LC) and leftover doughnuts (LD)

\begin{tabular}{|c|c|c|c|c|c|}
\hline \multirow{3}{*}{ Run order } & \multicolumn{3}{|c|}{ Independent variables } & \multicolumn{2}{|c|}{ Response } \\
\hline & \multirow{2}{*}{$\begin{aligned} \mathrm{X}_{1}= & \text { Enzyme concentration } \\
& (\mathrm{U} / \mathrm{g} \text { substrate })\end{aligned}$} & \multirow{2}{*}{$\mathrm{X}_{2}=$ Temperature $\left({ }^{\circ} \mathrm{C}\right)$} & \multirow{2}{*}{$\mathrm{X}_{3}=\mathrm{pH}$} & \multicolumn{2}{|c|}{ Total sugar yield (mg/g) } \\
\hline & & & & LC & LD \\
\hline 1 & 840 & 40 & 3.0 & $502.74 \pm 0.60$ & $136.63 \pm 0.60$ \\
\hline 2 & 840 & 60 & 3.0 & $435.89 \pm 0.45$ & $79.79 \pm 0.60$ \\
\hline 3 & 840 & 40 & 5.5 & $449.26 \pm 0.89$ & $90.63 \pm 0.74$ \\
\hline 4 & 840 & 60 & 5.5 & $414.32 \pm 0.30$ & $63.26 \pm 0.45$ \\
\hline 5 & 840 & 50 & 4.0 & $574.84 \pm 0.74$ & $214.95 \pm 0.89$ \\
\hline 6 & 1020 & 40 & 4.0 & $217.16 \pm 0.89$ & $254.32 \pm 0.30$ \\
\hline 7 & 1020 & 60 & 4.0 & $252.42 \pm 0.89$ & $227.79 \pm 0.89$ \\
\hline 8 & 1020 & 50 & 3.0 & $362.63 \pm 0.45$ & $346.53 \pm 0.89$ \\
\hline 9 & 1020 & 50 & 5.5 & $283.68 \pm 0.74$ & $267.47 \pm 0.45$ \\
\hline 10 & 1020 & 50 & 4.0 & $342.32 \pm 0.89$ & $326.11 \pm 0.60$ \\
\hline 11 & 1020 & 50 & 4.0 & $347.58 \pm 0.89$ & $324.32 \pm 0.45$ \\
\hline 12 & 1020 & 50 & 4.0 & $351.26 \pm 0.74$ & $324.11 \pm 0.74$ \\
\hline 13 & 1020 & 50 & 4.0 & $350.95 \pm 0.60$ & $326.32 \pm 0.30$ \\
\hline 14 & 1020 & 50 & 4.0 & $348.21 \pm 0.89$ & $327.47 \pm 0.74$ \\
\hline 15 & 1020 & 50 & 4.0 & $346.21 \pm 0.74$ & $324.21 \pm 0.30$ \\
\hline 16 & 1200 & 40 & 3.0 & $229.26 \pm 0.60$ & $441.89 \pm 0.89$ \\
\hline 17 & 1200 & 60 & 3.0 & $192.53 \pm 0.74$ & $361.79 \pm 0.45$ \\
\hline 18 & 1200 & 40 & 5.5 & $201.47 \pm 0.30$ & $410.63 \pm 0.45$ \\
\hline 19 & 1200 & 60 & 5.5 & $157.79 \pm 0.45$ & $350.79 \pm 0.30$ \\
\hline 20 & 1200 & 50 & 4.0 & $246.32 \pm 0.60$ & $453.47 \pm 0.89$ \\
\hline
\end{tabular}


SCANNING ELECTRON MICROSCOPY (SEM) ANALYSIS

The characterization of morphological properties of LC and LD was executed using Scanning Electron Microscope (SEM) Hitachi S-3400N Tabletop Microscope. The aim of this analysis was to observe any changes, particularly of the surface of the residue due to enzymatic hydrolysis. The hydrolysates taken from enzymatic hydrolysis of LC and LD were dried in the oven at $105^{\circ} \mathrm{C}$ for 24 hours prior to SEM viewing. Next, the samples were attached on stubs and sputter-coated with a layer of gold. By using an accelerating voltage of $10.0 \mathrm{kV}$, the SEM micrographs of LC and LD were viewed.

FOURIER TRANSFORM-INFRARED (FT-IR) ANALYSIS FTIR analysis was carry out for identifying the presence of functional groups or chemicals bonds in the hydrolysates from LC and LD through enzymatic hydrolysis, by using PerkinElmer SpectrumTM 100 FTIR spectrometer (PerkinElmer) with spectral range of $400-4000 \mathrm{~cm}^{-1}$ at 200 scans per second. A plot of infrared radiation intensity versus wave number was recorded for LC and LD sugar recovered at optimal condition to qualitatively identify the functional groups of the samples.

\section{HYDROXYMETHYLFURFAL (HMF) ANALYSIS}

The detection and quantitative evaluation of hydroxymethylfurfural was conducted according to the method by Bogdanov (2009). Using High Performance Liquid Chromatography (HPLC), with a mobile phase of water: methanol (90:10 by volume) and a C18-reversed phase material column. $20 \mu \mathrm{L}$ of sample was injected at the flow rate of $1.0 \mathrm{~mL} / \mathrm{min}$, and HMF was detected using UV detection at $285 \mathrm{~nm}$. The quantification of HMF in the hydrolysate was determined by calculating the corresponding peak areas of the samples.

\section{RESULTS AND DISCUSSION}

\section{EFFECT OF PROCESS CONDITIONS ON TOTAL SUGAR YIELD AND SUGAR PROFILE}

Amyloglucosidase hydrolyzes $\alpha-1,4$ glycosidic and $\alpha-1,6$ linkages bonds from the non-reducing ends of starch, producing sugar (Keeratiburana et al. 2020). Furthermore, according to Ma et al. (2020), there are two ways on how amyloglucosidase hydrolyzed; 'outside-in' and 'insideout' pattern. For 'outside-in' pattern, amyloglucosidase molecules penetrate from specific areas towards granule matrices. Meanwhile, for 'inside-out' pattern amyloglucosidase molecules bind to channels and penetrate towards the central cavity or granule matrix. Considering the fact there are a few factors that can affect enzymatic hydrolysis, thus, this section would discuss the effect of process conditions (enzyme concentration, temperature, and $\mathrm{pH}$ ) on total sugar yield and sugar profile analysis.

The enzymatic hydrolysis of LC and LD was carried out at (120-1200 U/g substrate) enzyme concentration fixed at $50{ }^{\circ} \mathrm{C}$ and $\mathrm{pH} 5.5$. The total sugar yield of hydrolysate from LC and LD after enzymatic hydrolysis (EH) was presented in Figure 1.

Different process conditions showed different trends of total sugar yield for both LC and LD (Figure 1). From Figure 1(a), the enzyme concentration had a great effect on the total sugar yield. The amount of total sugar yield for LC increased from 120 to $840 \mathrm{U} / \mathrm{g}$ substrate until it yielded a maximum value of $275.16 \pm 0.19 \mathrm{mg} / \mathrm{g}$ (at $840 \mathrm{U} / \mathrm{g}$ substrate), but later decreased from 840 to $1200 \mathrm{U} / \mathrm{g}$ substrate. It can be observed that the amount of total sugar yield recorded for LC (until $720 \mathrm{U} / \mathrm{g}$ substrate) was higher than that of the LD. The different behaviour of hydrolysis between LC and LD might be due to the availability of the substrate (in the LC and LD) during the process. Further addition of enzyme concentration (840 - $1200 \mathrm{U} / \mathrm{g}$ substrate) has caused a decrease in sugar recovery in LC, which might be due to the excess of enzymes with limited substrates to be attacked and hydrolyzed the saccharides. Demirci et al. (2017) observed positive trends in recovering sugar when the enzyme concentration increased. Azmi et al. (2017) mentioned if enzyme concentration is insufficient, it will resulted a slower rate and low yield, whereas if enzyme concentration is in excess it can lead to underutilized of the enzymes. Thus, it can be concluded that a sufficient amount of enzyme (amyloglucosidase) was essential to catalyze the hydrolysis reaction, which breakdown the polysaccharides (carbohydrate) to sugars (oligo-, di- and monosaccharides), as well as facilitates in gaining high sugar yield.

The process temperature was observed to have a significant effect towards enzymatic hydrolysis process as each enzyme has its own optimum temperature for it to work efficiently. As the temperature increased, the rate of enzyme catalysed reaction increases due to the increase of enzyme activity. At a temperature from $30{ }^{\circ} \mathrm{C}$ to $50{ }^{\circ} \mathrm{C}$, the hydrolysates of LC and LD have recorded an increase in total sugar yield. The highest value for both LC and LD were recorded at $50{ }^{\circ} \mathrm{C}$, with $311.53 \pm 0.18 \mathrm{mg} / \mathrm{g}$ of total sugar yield for LC; and $308.89 \pm 0.28 \mathrm{mg} / \mathrm{g}$ for $\mathrm{LD}$. Further increment in temperature (from $50^{\circ} \mathrm{C}$ to $60^{\circ} \mathrm{C}$ ) has caused the sugar recovered from LC and LD to decrease. 
a)

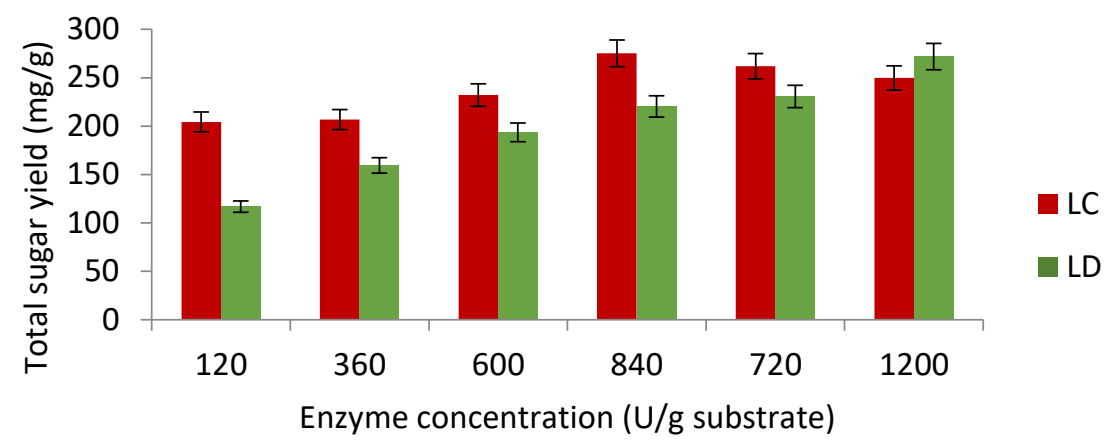

b)

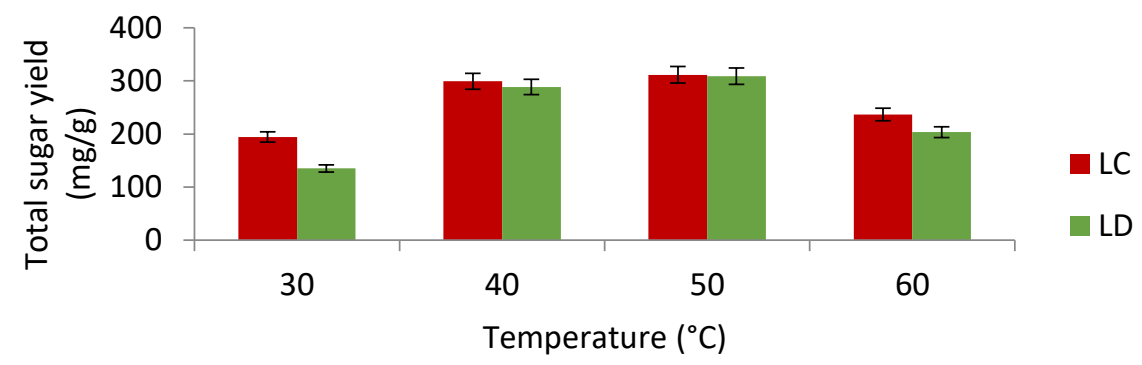

c)

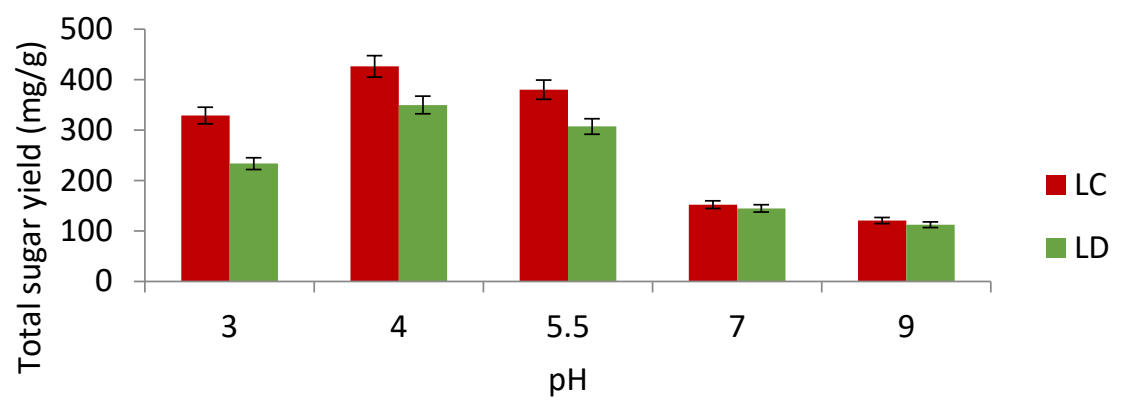

FIGURE 1. Total sugar yield (mg/g) of leftover croissant (LC) and doughnut (LD) hydrolysates prepared by enzymatic hydrolysis under various process conditions (a) Enzyme concentration (120-1200 U/g substrate at $50{ }^{\circ} \mathrm{C}$ min and $\mathrm{pH} 5.5$ ), (b) Temperature (30-60 min at $840 \mathrm{U} / \mathrm{g}$ substrate (LC), $1200 \mathrm{U} / \mathrm{g}$ substrate (LD) enzyme concentration and $\mathrm{pH} 5.5$ ), and (c) $\mathrm{pH}\left(3-9\right.$ at $840 \mathrm{U} / \mathrm{g}$ substrate (LC), $1200 \mathrm{U} / \mathrm{g}$ substrate (LD) enzyme concentration and $50{ }^{\circ} \mathrm{C}$ )

The reaction rate reached a maximum at a temperature of $50{ }^{\circ} \mathrm{C}$ and above this temperature, the enzyme becomes denatured. Hudečková et al. (2017) reported in their work that $55^{\circ} \mathrm{C}$ is the optimum temperature to obtain sugar from waste bread before fermentation. However, Pietrzak and Kawa-Rygielska (2015) who also employed amyloglucosidase to hydrolyze bread waste has found that $59^{\circ} \mathrm{C}$ was the best temperature in their work.

The $\mathrm{pH}$ condition during enzymatic hydrolysis was also crucial to ensure maximum sugar recovery from the LC and LD. According to Khanna (2010), pH can effect the ionization state of acidic or basic amino acids, where 
if its altered it may lead to enzyme's inactivity. From Figure 1(c), the enzymatic hydrolysis of LC and LD using amyloglucosidase seem to favour acidic condition where it is obvious that between $\mathrm{pH} 3$ and $\mathrm{pH} 5.5$, the process has yielded a high value of total sugar as compared to neutral (pH 7) and alkaline $\mathrm{pH}$ condition $(\mathrm{pH} 9)$. At $\mathrm{pH} \mathrm{4}$, the highest total sugar yield was obtained at $426.21 \pm 1.93 \mathrm{mg} / \mathrm{g}$ (LC) and $349.79 \pm 1.94 \mathrm{mg} / \mathrm{g}$ (LD). Han et al. (2012) reported that the changes in $\mathrm{pH}$ value may result in the loss of enzyme activity or dissociation between substrate and catalytic group of enzyme active center, leading to the reduced speed of enzymatic reaction. Hudečková et al. (2017) also had similar findings where the highest sugar obtained from enzymatic hydrolysis of waste bread was found to be at $\mathrm{pH} 4.2$.

Sugar profile analysis (Table 2) was carried out to scrutinize the hydrolysate from enzymatic hydrolysis of LC and LD using HPLC, where the two peaks corresponding to glucose and fructose were detected. From Table 2, the sugars recovered (glucose and fructose) from EH of LC and LD has significant effect $(p<0.05)$ towards processing conditions. As enzyme concentration increased, both glucose and fructose also increased, as observed on the total sugar yield. The highest fructose and glucose concentrations detected at $840 \mathrm{U} / \mathrm{g}$ substrate (LC) were $9.46 \pm 0.16 \mathrm{mg} / \mathrm{g}$ and $11.13 \pm 0.62 \mathrm{mg} / \mathrm{g}$, respectively, and $10.10 \pm 0.12 \mathrm{mg} / \mathrm{g}$ and $12.76 \pm 0.18 \mathrm{mg} / \mathrm{g}$, respectively, for LD at $1200 \mathrm{U} / \mathrm{g}$ substrate. However, glucose and fructose started to slowly decrease for LC as enzyme concentration increased from 840 to $1200 \mathrm{U} / \mathrm{g}$ substrate. The reduction of glucose and fructose may be due to enzyme saturation. When the enzyme concentration increased but the amount of substrate (LC) remains the same, less substrate is available for enzyme to attack. As this happened, the enzymatic hydrolysis efficiency will decrease, consequently reducing the total sugar yield.

TABLE 2. The monosaccharide contents of the hydrolysate obtained from the enzymatic hydrolysis of leftover croissants (LC) and doughnuts (LD) with various process conditions $(p<0.05)$

\begin{tabular}{|c|c|c|c|c|c|}
\hline \multicolumn{2}{|c|}{ Process conditions } & \multicolumn{2}{|c|}{ Leftovers croissants (LC) } & \multicolumn{2}{|c|}{ Leftovers doughnuts (LD) } \\
\hline & & $\begin{array}{l}\text { Glucose (mg /g } \\
\text { substrate) }\end{array}$ & $\begin{array}{c}\text { Fructose }(\mathrm{mg} / \mathrm{g} \\
\text { substrate) }\end{array}$ & $\begin{array}{c}\text { Glucose }(\mathrm{mg} / \mathrm{g} \\
\text { substrate) }\end{array}$ & $\begin{array}{c}\text { Fructose (mg/g } \\
\text { substrate) }\end{array}$ \\
\hline \multirow{6}{*}{$\begin{array}{c}\text { Enzyme concentration } \\
\text { (U/g substrate) at } 50{ }^{\circ} \mathrm{C} \\
\text { and } \mathrm{pH} 5.5\end{array}$} & 120 & $5.80 \pm 0.59$ & $6.10 \pm 0.70$ & $4.44 \pm 0.64$ & $4.63 \pm 0.27$ \\
\hline & 360 & $5.87 \pm 0.59$ & $6.20 \pm 0.69$ & $6.50 \pm 0.62$ & $5.77 \pm 0.57$ \\
\hline & 600 & $9.50 \pm 0.74$ & $8.96 \pm 0.53$ & $8.62 \pm 0.42$ & $7.40 \pm 0.71$ \\
\hline & 840 & $11.13 \pm 0.62$ & $9.46 \pm 0.16$ & $8.73 \pm 0.31$ & $8.21 \pm 0.12$ \\
\hline & 720 & $10.85 \pm 0.78$ & $8.83 \pm 0.72$ & $12.09 \pm 0.55$ & $9.38 \pm 0.26$ \\
\hline & 1200 & $10.17 \pm 0.60$ & $8.60 \pm 0.24$ & $12.76 \pm 0.18$ & $10.10 \pm 0.12$ \\
\hline \multirow{4}{*}{$\begin{array}{c}\text { Temperature }\left({ }^{\circ} \mathrm{C}\right) \text { at } \\
\text { enzyme concentration } \\
840 \mathrm{U} / \mathrm{g} \text { substrate }(\mathrm{LC}) \\
1200 \mathrm{U} / \mathrm{g} \text { substrate } \\
\text { (LD); and pH } 5.5\end{array}$} & 30 & $8.91 \pm 0.13$ & $9.56 \pm 0.03$ & $3.85 \pm 0.24$ & $2.75 \pm 0.66$ \\
\hline & 40 & $10.10 \pm 0.28$ & $10.54 \pm 0.21$ & $9.23 \pm 0.92$ & $9.99 \pm 0.48$ \\
\hline & & $1071+1$ & 1057000 & 10060000 & $1200+005$ \\
\hline & 60 & $037+047$ & $965+002$ & $802+037$ & $767+041$ \\
\hline \multirow{6}{*}{$\begin{array}{c}\mathrm{pH} \text { at enzyme } \\
\text { concentration } 840 \mathrm{U} / \mathrm{g} \\
\text { substrate (LC) } 1200 \\
\mathrm{U} / \mathrm{g} \text { substrate (LD); and } \\
50^{\circ} \mathrm{C}\end{array}$} & 3 & $924+010$ & $1182+0.01$ & $867+03$ & $1106+0.06$ \\
\hline & & & & & \\
\hline & 4 & $11.84 \pm 0.21$ & $14.47 \pm 0.73$ & $10.34 \pm 0.11$ & $13.26 \pm 0.63$ \\
\hline & 5.5 & $11.2 \pm 0.29$ & $12.42 \pm 0.39$ & $9.89 \pm 0.03$ & $11.51 \pm 0.03$ \\
\hline & 7 & $8.28 \pm 0.95$ & $10.71 \pm 0.25$ & $3.84 \pm 0.12$ & $5.16 \pm 0.05$ \\
\hline & 9 & $2.68 \pm 1.03$ & $0.86 \pm 1.13$ & $1.13 \pm 0.35$ & $1.85 \pm 0.28$ \\
\hline
\end{tabular}


The enzymatic hydrolysis was carried out at an enzyme concentration of $840 \mathrm{U} / \mathrm{g}$ substrate and $1200 \mathrm{U} / \mathrm{g}$ substrate, for $\mathrm{LC}$ and $\mathrm{LD}$, respectively, at temperature 30-60 ${ }^{\circ} \mathrm{C}$ and $\mathrm{pH}$ 5.5. Different types of enzyme require different temperature to achieve high efficiency. From Table 2, glucose and fructose increased as the temperature increased for both LC and LD. Highest glucose and fructose yield were recorded for LC and LD at temperature $50{ }^{\circ} \mathrm{C}$, with $10.71 \pm 0.15 \mathrm{mg}$ glucose/g and $12.57 \pm 0.08$ $\mathrm{mg}$ fructose $/ \mathrm{g}$ for LC and $10.86 \pm 0.09 \mathrm{mg}$ glucose $/ \mathrm{g}$ and $12.08 \pm 0.95 \mathrm{mg}$ fructose $/ \mathrm{g}$ for LD. During enzymatic hydrolysis, in order to convert LC and LD into glucose and fructose, the enzyme (amyloglucosidase) must collide and bind to the substrate at its active site. An increase in temperature during the process will increase the number of collisions of the enzyme and substrate per unit time. Thus, the rate of an enzyme-catalysed reaction increases as the temperature is raised. Han et al. (2016) has recorded 55 ${ }^{\circ} \mathrm{C}$ as the optimum temperature for enzymatic hydrolysis of food waste using amyloglucosidase. Nonetheless, when the temperature further increased to $60{ }^{\circ} \mathrm{C}$, the glucose and fructose started to decrease, indicating that the temperature may be too high for amyloglucosidase and the denaturing phase has started.

In this work, the enzymatic hydrolysis of LC and LD was carried out with $\mathrm{pH}$ of 3-9, temperature of $50{ }^{\circ} \mathrm{C}$ and enzyme concentration of $840 \mathrm{U} / \mathrm{g}$ substrate (LC) and $1200 \mathrm{U} / \mathrm{g}$ substrate (LD). From Table 2, glucose and fructose were observed to increase from $\mathrm{pH} 3$ until pH 4 . However, glucose and fructose started to decrease as the condition shifted to neutral and alkaline ( $\mathrm{pH}$ 5.5-9). The highest glucose and fructose reported at $\mathrm{pH} 4$ for LC and LD with glucose and fructose of $11.84 \pm 0.21 \mathrm{mg} / \mathrm{g}$ and $14.47 \pm 0.73 \mathrm{mg} / \mathrm{g}$, and $10.34 \pm 0.11 \mathrm{mg} / \mathrm{g}$ and $13.26 \pm 0.63$ $\mathrm{mg} / \mathrm{g}$, respectively. In enzymatic hydrolysis, optimum $\mathrm{pH}$ is the point where the enzyme is most active, where higher or lower $\mathrm{pH}$ values than the optimum $\mathrm{pH}$ values can affect the stability and loss of enzyme activity. Optimum $\mathrm{pH}$ value varied according to the type of enzyme used. $\mathrm{pH}$ values played great influence during the binding process of enzyme and substrate at the active site, where the ions (from the surrounding) may affect the chemical bonding of enzyme and substrate. In this work, pH 4 was the most suitable for enzymatic hydrolysis of LC and LD. A study by Hudečková et al. (2017) on waste bread using amyloglucosidase has also reported $\mathrm{pH} 4.2$ as the optimal $\mathrm{pH}$ value for enzymatic hydrolysis.

\section{OPTIMIZATION OF PROCESS CONDITIONS USING RSM}

The best three levels of each factor (enzyme concentration at $0.7-1.0 \%(\mathrm{w} / \mathrm{w})$, process temperature at $40-60$
${ }^{\circ} \mathrm{C}$ and $\mathrm{pH}$ at 3-5.5.) are selected for designing the optimization of process conditions using Response Surface Methodology (RSM). The RSM was used to predict the optimum condition, which the hydrolysate and residue obtained at this condition were further characterize (these results will be discussed in the following section).

Analysis of variance (ANOVA) for the response of total sugar yield from LC and LD are presented in Table 3. ANOVA was used to investigate the influence of each independent variable (enzyme concentration $\left(\mathrm{X}_{1}\right)$, temperature $\left(\mathrm{X}_{2}\right)$ and $\left.\mathrm{pH}\left(\mathrm{X}_{3}\right)\right)$ in order to construct an empirical model. The model is then used to maximize the total sugar yield recovered from LC and LD through EH. The significance of each condition was obtained by examining its respective $p$-value. If the $p$-value $<0.05$, it indicates significance towards the response variable (total sugar yield).

Both LC and LD models were found to be significant $(\mathrm{p}<0.0001)$. Enzyme concentration and $\mathrm{pH}$ appeared to be the important variables for LC, as these variables were found to be significant ( $p<0.0001)$. Meanwhile, for LD, all of the independent variables (enzyme concentration, temperature and $\mathrm{pH}$ ) were found to be significant $(\mathrm{p}<$ 0.0001). For quadratic factor term, enzyme concentration $\left(\mathrm{X}_{1} \mathrm{X}_{1}\right)$ and temperature $\left(\mathrm{X}_{2} \mathrm{X}_{2}\right)$ were significant $(\mathrm{p}$ $=0.0005$ and $p=0.0001$ ) for LC and for LD only temperature $\left(X_{2} X_{2}\right)$ was significant $p<0.0001$, while the other variables were not significant. For interaction factor term, all the variables were found not significant for both LC and LD. The coefficients of determination $\left(\mathrm{R}^{2}\right)$ for sugar yields of LC and LD were 0.9699 and 0.9882 , respectively, which indicate the experimental results were well represented by the model. Multiple regression analysis on the experimental data was performed, and the model for the response variable (total sugar yield) can be expressed using the following quadratic equation (shown in Table 3) in the form of coded values, after exclusion of the insignificant terms.

To illustrate the effects of the process conditions on sugar recovery of LC and LD via EH, 3D contour graphs of the response surface and experimental models are presented in Figures 2 and 3. From the graph, the enzyme concentration had a great effect on the total sugar yield. However, for LC, enzyme concentration has positive effect only to a certain value ( $840 \mathrm{U} / \mathrm{g}$ substrate) but later exhibit a negative effect where the increment in the amount of enzyme present during the process resulted in lowering total sugar yield. Positive trend was recorded for LD, where an increasing enzyme concentration had a positive effect on total sugar yield. Nonetheless, 
despite the negative effect of enzyme concentration for LC samples, it still had higher total sugar yield than LD. The divergent in the effect of enzyme concentration on total sugar yield might be due to the carbohydrate content on raw materials, whereby LC has higher carbohydrate content when compared to LD.

TABLE 3. Analysis of variance (ANOVA) model for the total sugar yields of the leftover croissants (LC) and leftover donuts (LD) via EH

\begin{tabular}{|c|c|c|c|c|c|c|c|c|c|c|c|c|}
\hline \multirow{2}{*}{ Source } & \multicolumn{5}{|c|}{ LC } & \multirow[t]{2}{*}{ Comment } & \multicolumn{5}{|c|}{ LD } & \multirow[t]{2}{*}{ Comment } \\
\hline & $\begin{array}{l}\text { Sum of } \\
\text { squares }\end{array}$ & $\mathrm{DF}$ & $\begin{array}{c}\text { Mean } \\
\text { square }\end{array}$ & F-value & p-value & & $\begin{array}{l}\text { Sum of } \\
\text { squares }\end{array}$ & DF & $\begin{array}{l}\text { Mean } \\
\text { square }\end{array}$ & F-value & p-value & \\
\hline Model & $2.216 \mathrm{E}+005$ & 9 & 24619.38 & 35.74 & $<0.0001$ & Significant & $2.500 \mathrm{E}+005$ & 9 & 27779.08 & 93.17 & $<0.0001$ & Significant \\
\hline \multicolumn{13}{|l|}{$\underline{\text { Linear }}$} \\
\hline $\mathrm{X}_{1}$ & $1.815 \mathrm{E}+005$ & 1 & $1.815 \mathrm{E}+005$ & 263.49 & $<0.0001$ & Significant & $2.055 \mathrm{E}+005$ & 1 & $2.055 \mathrm{E}+005$ & 689.06 & $<0.0001$ & Significant \\
\hline $\mathrm{X}_{2}$ & 2137.39 & 1 & 2137.39 & 3.10 & 0.1086 & & 6160.39 & 1 & 6160.39 & 20.66 & 0.0011 & Significant \\
\hline $\mathrm{X}_{3}$ & 4688.52 & 1 & 4688.52 & 6.81 & 0.0261 & Significant & 3380.08 & 1 & 3380.08 & 11.34 & 0.0072 & Significant \\
\hline \multicolumn{13}{|l|}{ Quadratic } \\
\hline $\mathrm{X}_{1} \mathrm{X}_{1}$ & 18028.38 & 1 & 18028.38 & 26.18 & 0.0005 & Significant & 437.13 & 1 & 437.13 & 1.47 & 0.2538 & \\
\hline $\mathrm{X}_{2} \mathrm{X}_{2}$ & 24725.97 & 1 & 24725.97 & 35.90 & 0.0001 & Significant & 17841.62 & & 17841.62 & 59.84 & $<0.0001$ & Significant \\
\hline $\mathrm{X}_{3} \mathrm{X}_{3}$ & 12.30 & 1 & 12.30 & 0.0018 & 0.8963 & & 324.67 & & 324.67 & 1.09 & 0.3213 & \\
\hline \multicolumn{13}{|l|}{ Interaction } \\
\hline $\mathrm{X}_{1} \mathrm{X}_{2}$ & 57.14 & 1 & 57.14 & 0.083 & 0.7792 & & 388.23 & 1 & 388.23 & 1.30 & 0.2804 & \\
\hline$X_{1} X_{3}$ & 72.85 & 1 & 72.85 & 0.11 & 0.7517 & & 110.85 & 1 & 110.85 & 0.37 & 0.5556 & \\
\hline $\mathrm{X}_{2} \mathrm{X}_{3}$ & 17.95 & 1 & 17.95 & 0.026 & 0.8750 & & 251.21 & 1 & 251.21 & 0.84 & 0.3803 & \\
\hline Residual & 6887.53 & 10 & 6887.75 & & & & 2981.68 & 10 & 298.17 & & & \\
\hline Pure Error & 54.66 & 5 & 10.93 & & & & 9.88 & 5 & 1.98 & & & \\
\hline $\mathrm{R}^{2}$ & 0.9699 & & & & & & 0.9882 & & & & & \\
\hline $\begin{array}{l}\text { Model } \\
\text { Equation }\end{array}$ & \multicolumn{6}{|c|}{$\begin{array}{c}\text { Total Sugar Yield }=336.26-134.85 \mathrm{X}_{1}-14.63 .56 \mathrm{X}_{2}-21.56 \mathrm{X}_{3} \\
+2.67 \mathrm{X}_{1} \mathrm{X}_{2}+3.01 \mathrm{X}_{1} \mathrm{X}_{3}+1.49 \mathrm{X}_{2} \mathrm{X}_{3}+80.97 \mathrm{X}_{1} \mathrm{X}_{1}-94.82 \mathrm{X}_{2} \mathrm{X}_{2}-2.22 \mathrm{X}_{3} \mathrm{X}_{3}\end{array}$} & \multicolumn{6}{|c|}{$\begin{array}{c}\text { Total Sugar Yield }=320.67+143.48 \mathrm{X}_{1}-24.84 \mathrm{X}_{2}-18.39 \mathrm{X}_{3}- \\
6.97 \mathrm{X}_{1} \mathrm{X}_{2}+3.71 \mathrm{X}_{1} \mathrm{X}_{3}+5.58 \mathrm{X}_{2} \mathrm{X}_{3}+12.61 \mathrm{X}_{1} \mathrm{X}_{1}-80.55 \mathrm{X}_{2} \mathrm{X}_{2}-11.38 \mathrm{X}_{3} \mathrm{X}_{3}\end{array}$} \\
\hline
\end{tabular}

Both LC and LD display similar trends of total sugar yield for the effect of temperature (Figures 2(b) and $3(\mathrm{~b}))$, where both contour model favour a middle level of temperature $\left(50^{\circ} \mathrm{C}\right)$ to obtain highest total sugar yield. Previous studies by Demirci et al. (2017) and Hudečková et al. (2017) also recorded that medium temperature (55$60{ }^{\circ} \mathrm{C}$ ) produce a high yield of sugar from bread waste using the same type of enzyme (amyloglucosidase). At lower temperature $\left(40^{\circ} \mathrm{C}\right)$, the heat available may not be sufficient for the reaction rate to achieve optimal hydrolysis process, while higher temperature $\left(60^{\circ} \mathrm{C}\right)$ may cause the denaturation phase to occur. Hence, in this work, it was found that $50{ }^{\circ} \mathrm{C}$ was the optimum temperature for enzymatic hydrolysis of LC and LD. 
a)

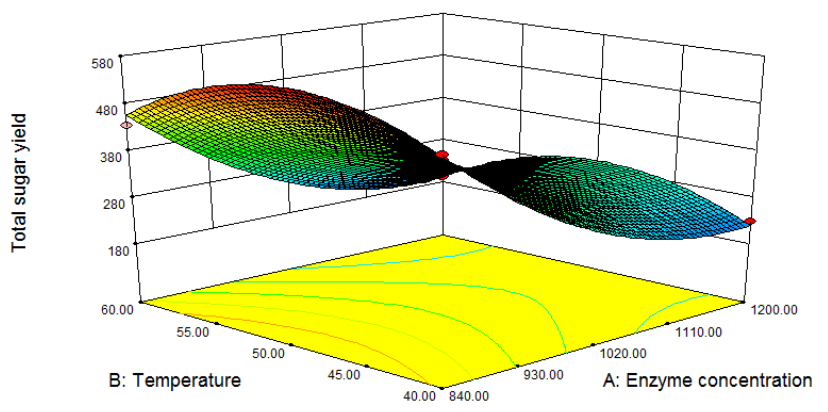

b)

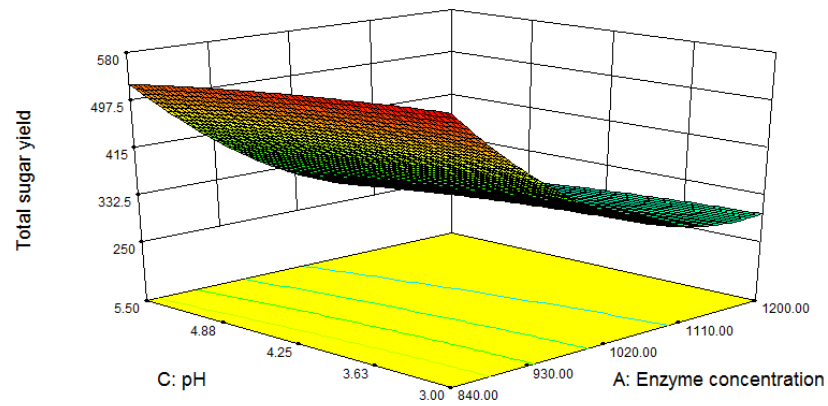

c)

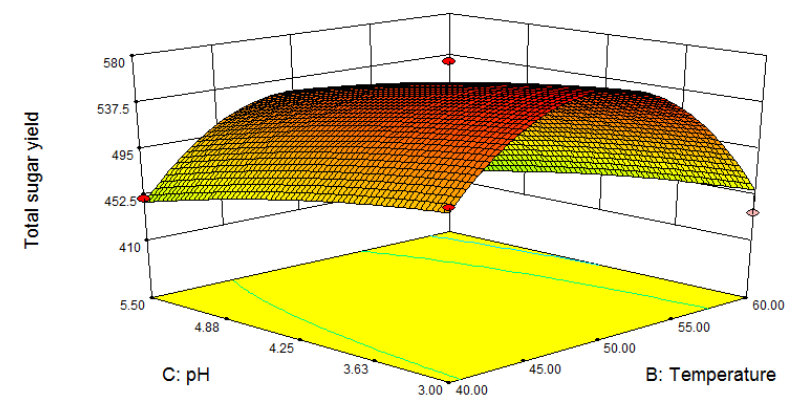

FIGURE 2. Response surface and contour graphs for total sugar yield of the leftover croissants (LC) as function of enzyme concentration (U/g substrate), temperature and $\mathrm{pH}$ via enzymatic hydrolysis

Finally, the other parameter that affects total sugar yield from LC and LD is the $\mathrm{pH}$ of the solution. From previous section, it is stated that enzymatic hydrolysis of LC and LD using amyloglucosidase seem to favour acidic condition (pH 3 to 5.5). Figures 2(b), 2(c), 3(b) and $3(\mathrm{c})$ show that between this $\mathrm{pH}$ range, small changes on the total sugar yield was observed. Hudečková et al. (2017) also had the same finding where the optimum sugar yield from wheat-rye bread through enzymatic hydrolysis where at acidic condition ( $\mathrm{pH} 4.2)$.

Optimization process was carried out to determine the optimal process condition of all parameters (enzyme concentration, temperature and $\mathrm{pH}$ ), with the aim to obtain a maximum total sugar yield from LC and LD. Table 4 displays the predicted optimal process conditions suggested by RSM and also comparison between the 
actual validation experimental results of LC and LD. The response (total sugar yield) was also presented. Insignificant difference $(<1 \%)$ was observed between the predicted and actual data for both LC and LD. This indicates the validity of the RSM model to confirm that the response model is adequate for predicting optimisation parameters of $\mathrm{EH}$.

a)

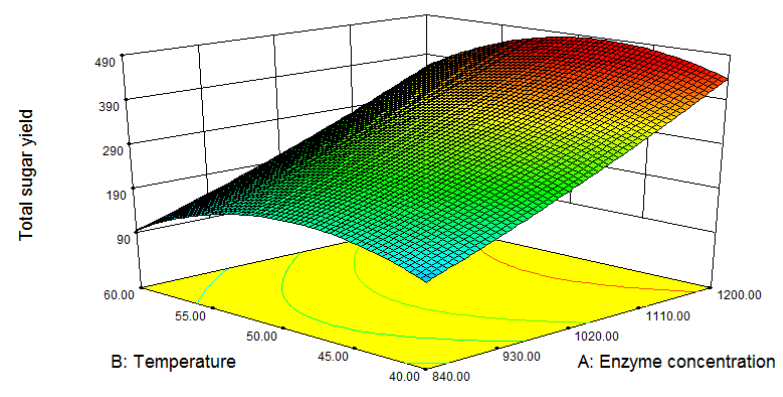

b)

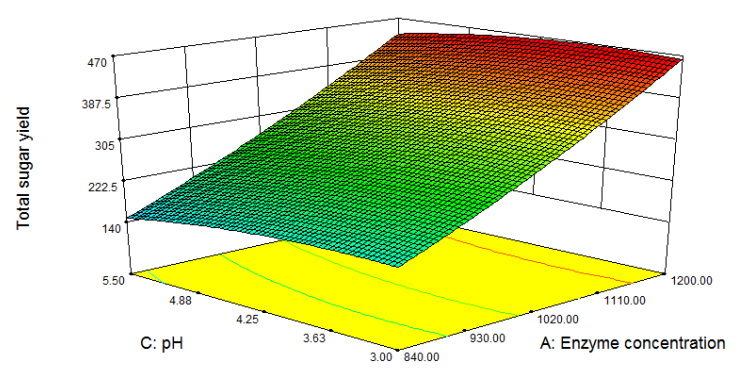

c)

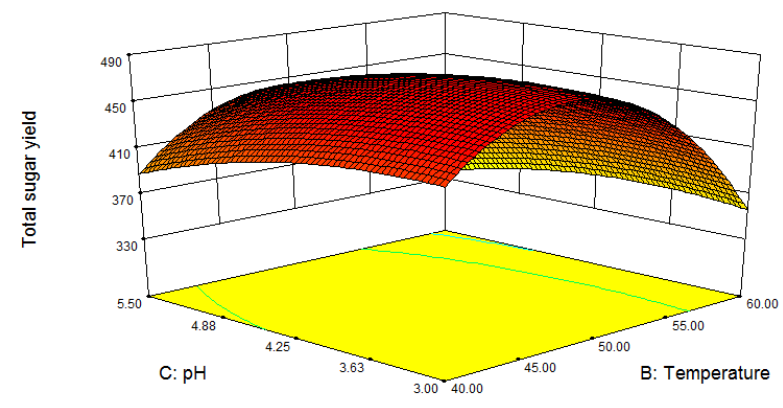

FIGURE 3. Response surface and contour graphs for total sugar yield of the leftover doughnuts (LD) as function of enzyme concentration, temperature and $\mathrm{pH}$ via enzymatic hydrolysis 
TABLE 4. Response surface methodology (RSM) predicted and actual experimental process conditions with total sugar yield of the leftover croissants (LC) and leftover doughnuts (LD)

\begin{tabular}{|c|c|c|c|c|c|c|}
\hline & & $\begin{array}{c}\text { Enzyme } \\
\text { concentration (U/g } \\
\text { substrate) }\end{array}$ & Temperature $\left({ }^{\circ} \mathrm{C}\right)$ & $\mathrm{pH}$ & $\begin{array}{l}\text { Total sugar } \\
\text { yield (mg/g) }\end{array}$ & $\begin{array}{c}\text { Difference } \\
(\%)\end{array}$ \\
\hline \multirow{3}{*}{ LC } & Predicted & 840 & 48.53 & 3.01 & 575 & \multirow{3}{*}{0.14} \\
\hline & & & & & & \\
\hline & Actual & 840 & 49 & 3 & $574.21 \pm 0.74$ & \\
\hline \multirow{3}{*}{ LD } & Predicted & 1176 & 46.93 & 3.19 & 460.04 & \multirow{3}{*}{0.11} \\
\hline & & & & & & \\
\hline & Actual & 1176 & 47 & 3 & $460.53 \pm 0.74$ & \\
\hline
\end{tabular}

OPTIMIZATION ON PROCESS CONDITIONS FOR SUGAR RECOVERY FROM THE LEFTOVERS

SEM analysis was carried out on the residue of LC and $\mathrm{LD}$ after $\mathrm{EH}$, where the effects of enzymatic hydrolysis can be determined through assessing the morphological changes. SEM analysis is crucial to this study as it provides images and examined the structure and surface of the molecules before/after $\mathrm{EH}$, considering that enzymatic hydrolysis involved gelatinization and saccharification of starch molecules that leads to alteration on the structure of the molecule. Figure 4 shows the cell surface of the solid sample after EH at optimum condition.
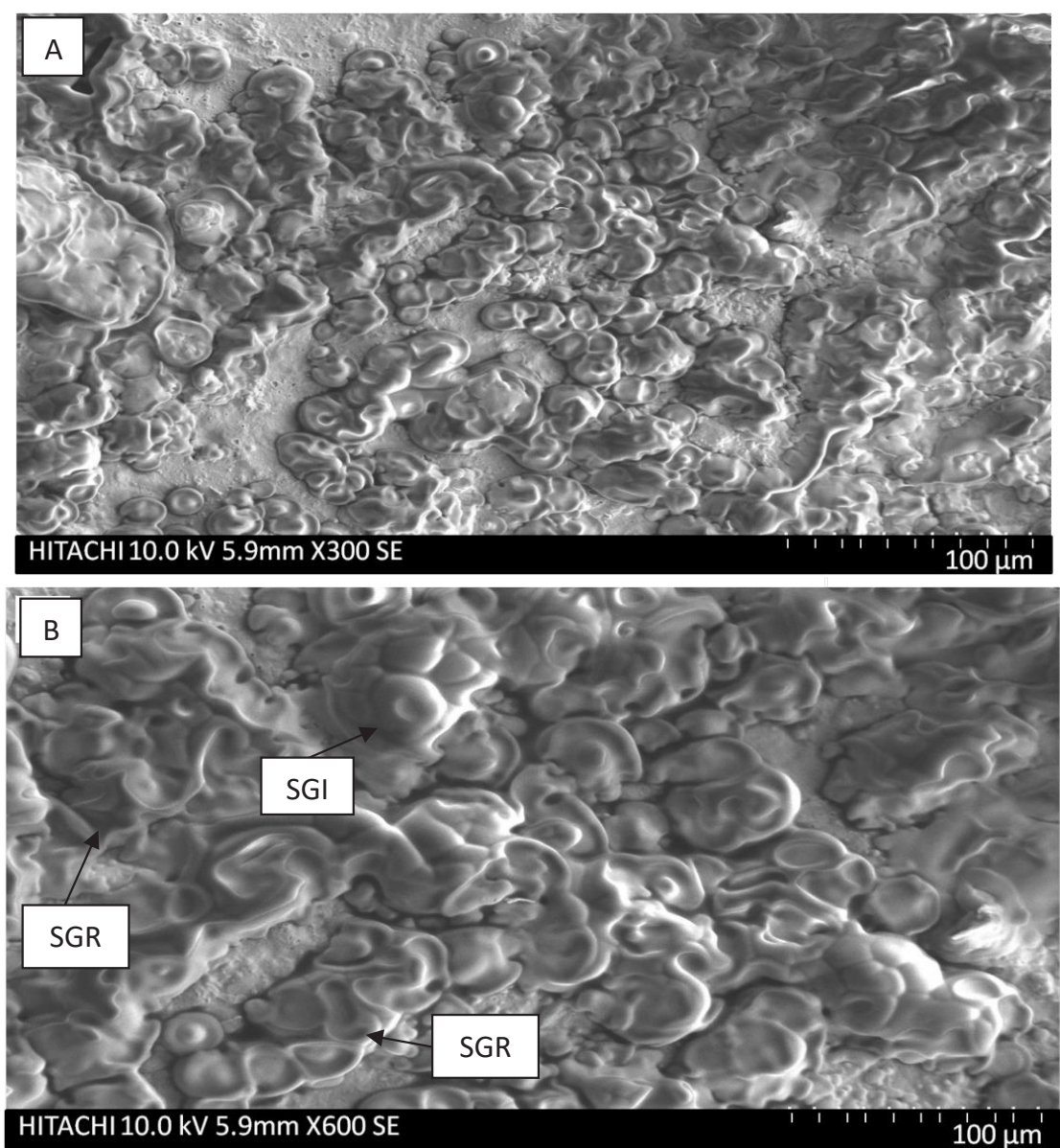

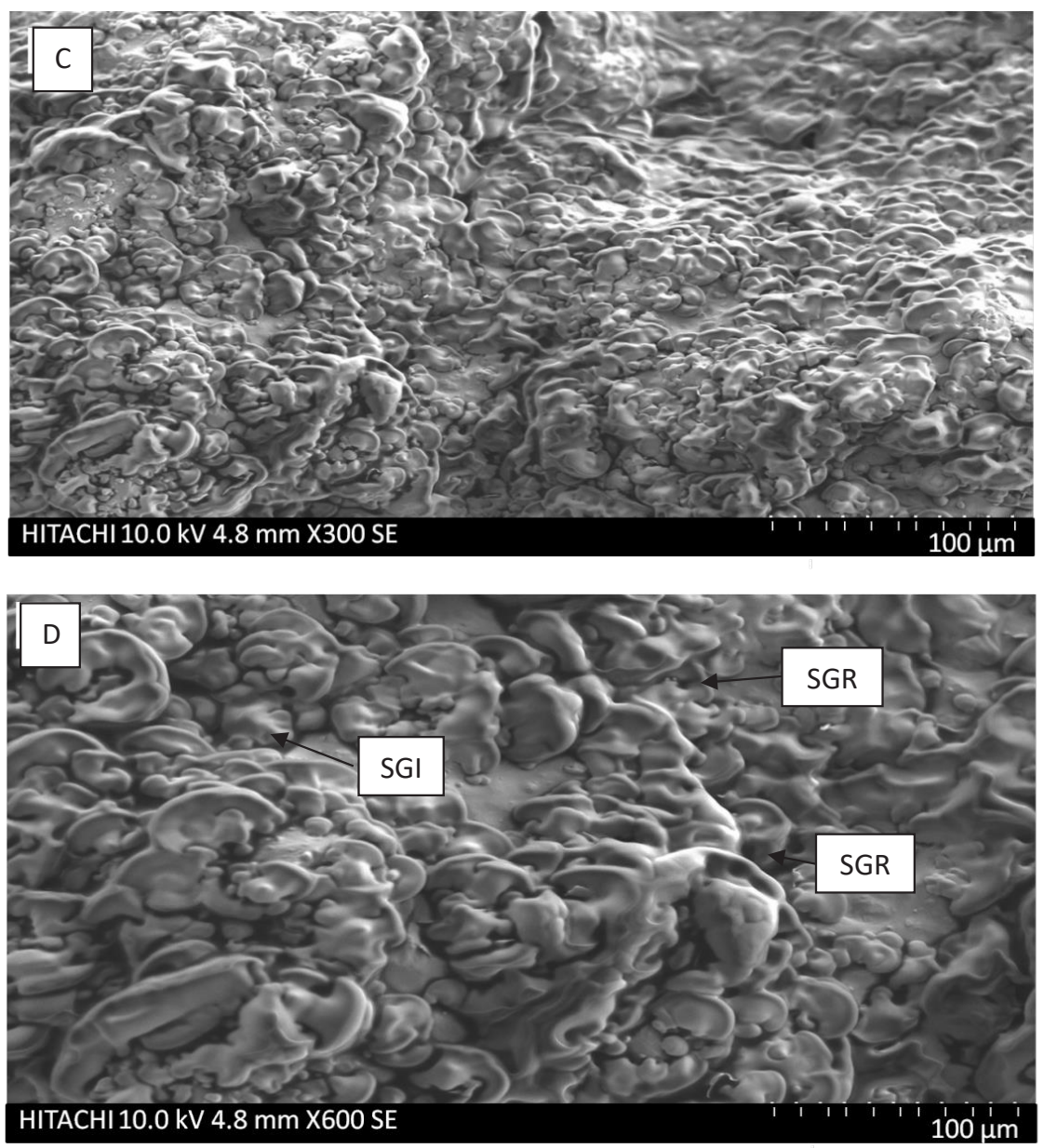

FIGURE 4. Scanning electron microscopy (SEM) images of (A) optimized residue sample of LC at 300× magnification; (B) optimized residue sample of LC at $600 \times$ magnification; (C) optimized residue sample of $L D$ at $300 \times$ magnification; and (D) optimized residue sample at $600 \times$ magnification of LD. SGI: Starch granules intact, SGR: Starch granules ruptured

According to Mohd Thani et al. (2020b) that had observed the raw materials of LC and LD, there was no obvious difference on the surface of raw samples. They stated that the starch granules in the raw samples were still intact and embedded within the protein matrix. Hesso et al. (2015) explained, during preparation, when flour and water were mixed, a reticular structure of proteins and soluble solutes in the form of a matrix with embedded starch granules. The preparation formula may affect the gluten-starch network. However, after the EH (Figure 4), the starch granules seems to shrink which might indicate the gelatinization and the release of amylose from the granules. Rojas et al. (2000) explained that during enzymatic attack, the granules displayed as perforated granules due to the enzyme activity. Both LC and LD after EH showed changes on the starch granules but LD seems to have some starch granules that were still intact in its original form. In contrary, majority of starch granules within LC have all shrunk, which has been proven with higher total sugar yield. From SEM, the changes on the structure of the starch granules, can validate the previous findings where LC had higher total sugar yield than LD.

FTIR analysis was carried out to scrutinize the chemical composition for both LC and LD hydrolysate that obtain after EH. Figure 5 shows that the trends on the IR spectra of LC and LD hydrolysate were almost similar. However, in the two samples, several peaks exhibited different sizes. 


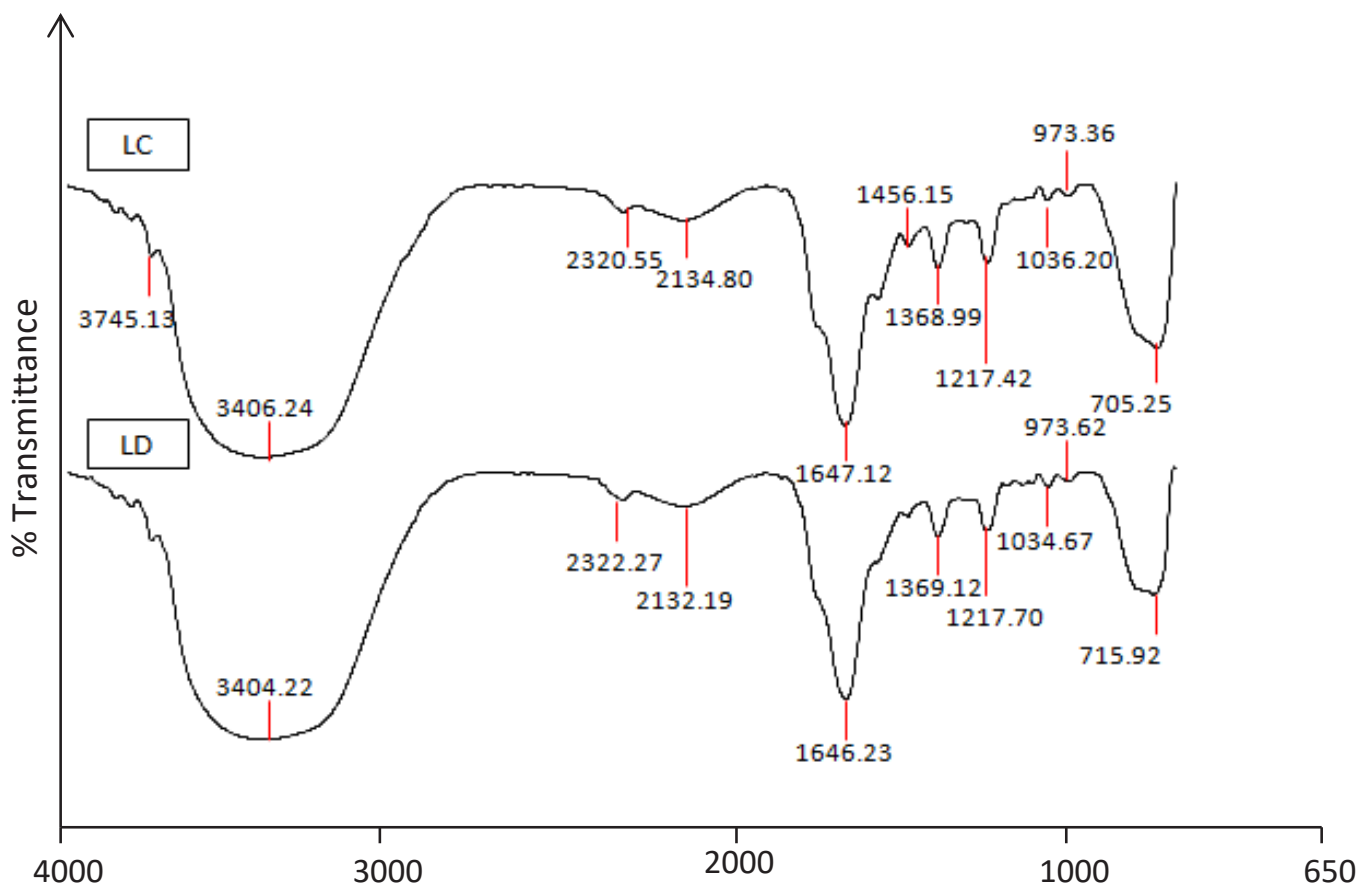

FIGURE 5. IR Spectra of hydrolysate from leftover croissants (LC) and leftover doughnuts (LD) after EH

The broadest peak detected was a hydroxyl group $(-\mathrm{OH})$, between $3000 \mathrm{~cm}^{-1}$ and $4000 \mathrm{~cm}^{-1}$. This finding was expected as the EH involved a portion of water molecules, thus there is no significant difference in this region between both samples. Polysaccharides, which consists of C-C and C-O stretching vibration 950 - 1200 $\mathrm{cm}^{-1}$, while band between $1200-1500 \mathrm{~cm}^{-1}$ are indicating the $\mathrm{C}-\mathrm{H}$ deformation vibrations and $\mathrm{C}-\mathrm{OH}$ bending vibrations (Ge et al. 2009; Huang \& Zhang 2009; Xu et al. 2009). Sugar monomers, such as sucrose, glucose, and fructose lie in the band $900-1500 \mathrm{~cm}^{-1}$ region (Anjos et al. 2015). From Figure 5, the peaks in this region were strong (intensified in terms of its width and height) for LC as compared to LD. This supports the previous findings that LC has a higher total sugar yield than LD.

EH treatment on LC and LD might produce a byproduct (hydroxymethylfurfural (HMF)) due to sugar degradation. Therefore, in order to determine the possible HMF produced during EH, both hydrolysate samples (LC and LD) were analyzed using HPLC. It was found that HMF content in both hydrolysate samples was relatively low, where LC has slightly higher HMF content than $\mathrm{LD}, 0.043 \pm 0.0334 \mathrm{mg} / \mathrm{g}$ and $0.023 \pm 0.0124 \mathrm{mg} / \mathrm{g}$, respectively. The distinction of HMF contents might be due to different process conditions, as for LC ( 840
$\mathrm{U} / \mathrm{g}$ substrate, $49^{\circ} \mathrm{C}$ and $\left.\mathrm{pH} 3\right)$ and for $\mathrm{LD}(1176 \mathrm{U} / \mathrm{g}$ substrate, $47{ }^{\circ} \mathrm{C}$ and $\mathrm{pH} 3$ ). The factor that might affect HMF formation during $\mathrm{EH}$ is the carbohydrate content of LC and LD, where the LC had a higher carbohydrate content $(52.42 \pm 0.29 \%)$ than the LD $(46.59 \pm 0.23 \%)$. Thus, more sugar molecules were available to be hydrolysed and further degraded into HMF and/or other by-products.

\section{CONCLUSION}

This study has proven that sugar can be recovered from LC and LD through enzymatic hydrolysis. Among the process conditions studied, enzyme concentration has the greatest effect on LC and LD. The initial carbohydrate percentage within the sample prior to $\mathrm{EH}$ also influenced the yield of sugar recovered, as LC has higher total sugar yield than LD, regardless of the process conditions. From RSM, it was found the optimum process condition for LC and LD were; $840 \mathrm{U} / \mathrm{g}$ substrate, $49{ }^{\circ} \mathrm{C}$ and $\mathrm{pH} 3$ with sugar yield of $574.21 \pm 0.74 \mathrm{mg} / \mathrm{g}$ and $1176 \mathrm{U} / \mathrm{g}$ substrate, $47{ }^{\circ} \mathrm{C}$ and $\mathrm{pH} 3.19$ with total sugar yield of $460.53 \pm 0.74 \mathrm{mg} / \mathrm{g}$, respectively. Further characterization on the sugar recovered from optimal process conditions, had shown that from morphological analysis of the residue, enzymatic hydrolysis has an impact on the 
structure of the starch granules, where the granules have shrunken indicating the occurrence of gelatinization process. While from FTIR analysis, it was found that the sugar recovered not only contained monosaccharides, but also oligosaccharides. The HMF content of LC has outnumbered LD due to the initial content of carbohydrate in LC. Thus, through enzymatic hydrolysis process, bakery leftovers can be potentially utilized for sugar recovery. Also, the findings from this work can facilitate for scaling up of the enzymatic hydrolysis process.

\section{ACKNOWLEDGEMENTS}

This study was supported by the Geran Putra IPS (Vote no. 9573200) from Universiti Putra Malaysia.

\section{REFERENCES}

Akpinar, O., Erdogan, K., Bakir, U. \& Yilmaz, L. 2009. Enzymatic production of xylooligosaccharide from selected agricultural wastes. Food and Bioproducts Processing 87(2): 145-151.

Amezcua-Allieri, M., Duran, T. \& Aburto, J. 2017. Study of chemical and enzymatic hydrolysis of cellulosic materials to obtain fermentable sugars. Journal of Chemistry 2017: 5680105.

Anjos, O., Campos, M., Ruiz, P. \& Antunes, P. 2015. Application of FTIR-ATR spectroscopy to the quantification of sugar in honey. Food Chemistry 169: 218-223.

Azmi, A.S., Malek, M.I.A. \& Puad, N.I.M. 2017. A review on acid and enzymatic hydrolyses of sago starch. International Food Research Journal 24(suppl): 265-273.

Bogdanov, S. 2009. Harmonised methods of the International Honey Commission. International Honey Commission.

Demirci, A., Palabiyik, I., Gumus, T. \& Ozalp, S. 2017. Waste bread as a biomass source: Optimization on enzymatic hydrolysis and relation between rheological behaviour and glucose yield. Waste Biomass Valor. 8: 775-782.

Fazil, F., Azzimi, N. \& Zubairi, S. 2018. Response surface optimization on the total phenolic content and antioxidant activities of Sabah Snake Grass (Clinacanthus nutans) leaves and Peleg kinetic modelling extract. International Food Research Journal 25(Suppl.1): S105-S115.

FAO. 2013. Food Loss and Waste: Definition and Scope.

Ge, Q., Zhang, A. \& Sun, P. 2009. Structural investigation of a novel water-soluble heteropolysaccharide from the fruiting bodies of Phellinus baumii Pilat. Food Chemistry 114: 391-395.

Gustavsson, J., Cederberg, C., Sonesson, U., van Otterdijk, R. \& Meybeck, A. 2011. Global Food Losses and Food Waste. Rome: Food and Agriculture Organization of the United Nations.

Han, W., Yan, Y., Shi, Y., Gu, J., Tang, J. \& Zhao, H. 2016. Biohydrogen production from enzymatic hydrolysis of food waste in batch and continuous systems. Scientific Reports 6: 38395 .
Hesso, N., Garnier, C., Loisel, C., Chevallier, S., Bouchet, B. \& Le-Bail, A. 2015. Formulation effect study on batter and cake microstructure: Correlation with rheology and texture. Food Structure 5: 31-41.

Hozová, B., Turicova, R. \& Lenkeyova, I. 2002. Microbiological and sensory quality and stored croissant-type bakery products depending on external (sorbic acid) and internal (dough, aw value) conditions. Nahrung 46(3): 144-150.

Huang, Z. \& Zhang, L. 2009. Chemical structure of watersoluble polysaccharides from Rhizoma Panacis Japonici. Carbohydrate Resources 344: 1136-1140.

Hudečková, H., Supinova, P. \& Babak, L. 2017. Optimization of enzymatic hydrolysis of wwaste bread before fermentation. Acta Universitatis Agriculturae Et Silviculturae Mendelianae Brunensis 65: 35-40.

Keeratiburana, T., Hansen, A.R., Soontaranon, S., Blennow, A. \& Tongta, S. 2020. Porous high amylose rice starch modified by amyloglucosidase and maltogenic $\alpha$-amylase. Carbohydrate Polymers 230: 115611.

Khanna, P. 2010. Cell and Molecular Biology. New Delhi: I.K. International Publishing House.

Ma, M., Xu, Z., Li, P., Sui, Z. \& Corke, H. 2020. Removal of starch granule-associated proteins affects amyloglucosidase hydrolysis of rice starch granules. Carbohydrate Polymers 247: 116674

Mahfuzul Islam, S., Loman, A. \& Ju, L.K. 2018. High monomeric sugar yields from enzymatic hydrolysis of soybean meal and effects of mild heat pretreatments with chelators. Bioresource Technology 256: 438-445.

Mohd Thani, N., Mustapa Kamal, S., Taip, F., Sulaiman, A., Omar, R. \& Siajam, S.I. 2020a. Hydrolysis and characterization of sugar recovery from bakery waste under optimized subcritical water conditions. Journal of Food Science and Technology https://doi.org/10.1007/s13197-020-04345-1.

Mohd Thani, N., Mustapa Kamal, S.M., Taip, F.S., Sulaiman, A. \& Omar, R. 2020b. Consumers' delayed consumption of bakery products: Effect on physical and chemical properties. Journal of Agricultural and Food Engineering 2(2020): 0013. http://doi.org/10.37865/jafe.2020.0013.

Mohd Thani, N., Mustapa Kamal, S., Taip, F., Sulaiman, A. \& Omar, R. 2019. Effect of enzyme concentration on total reducing sugar from leftover croissants and doughnuts via enzymatic hydrolysis. Food Research 3(4): 313-316.

Morais, A. \& Rodrigues, M. 2018. Optimization and consumer acceptability of carob powder as cocoa substitute in lactosefree cashew nut almonds-based beverage. International Food Research Journal 25(6): 2268-2274.

Moult, J., Allan, S., Hewitt, C. \& Berners-Lee, M. 2018. Greenhouse gas emissions of food waste disposal options for UK retailers. Food Policy 77: 50-58.

Nielsen, S. 2010. Phenol-sulfuric acid method for total carbohydrates. In Food Science Texts Series, edited by Nielsen, S. New York: Springer. pp. 47-53.

Pietrzak, W. \& Kawa-Rygielska, J. 2015. Simultaneous saccharification and ethanol fermentation of waste wheatrye bread at very high solids loading: Effect of enzymatic liquefaction conditions. Fuel 147: 236-242. 
Posridee, K., Oonsivilai, A. \& Oonsivilai, R. 2018. Optimization of sweet cassava (Manihot esculents crantz.) crude extract with high maltodextrin level using response surface methodology. International Food Research Journal 25(Suppl.1): S51-S56.

Rasli, H. \& Sarbon, N. 2018. Optimization of enzymatic hydrolysis conditions and characterization of Shortfin scad (Decapterus macrosoma) skin gelatin hydrolysate using response surface methodology. International Food Research Journal 25(4): 1541-1549.

Rojas, J., Rosell, C., Benedito, d.B., Perez-Munuera, I. \& Lluch, M. 2000. The baking process of wheat rolls followed by cryo scanning electron microscopy. European Food Research and Technology 212(1): 57-63.

Sánchez, Ó. \& Cardona, C. 2008. Trends in biotechnological production of fuel ethanol from different feedstocks. Bioresource Technology 99: 5270-5295.

Ventour, L. 2008. WRAP Food Waste Report v2: The Food We Waste. Britain.: WRAP.

Wang, W., Kang, L., Wei, H., Arora, R. \& Lee, Y. 2011. Study on the decreased sugar yield in enzymatic hydrolysis of cellulosic substrate at high solid loading. Applied Biochemistry and Biotechnology 164(7): 1139-1149.

Wasswa, J., Tang, J. \& Gu, X. 2007. Optimimization of the production of hydrolysates from grass carp (Ctenopharyngodon idella) skin using alcalase. Food Biochemistry 32: 460-473.
Xu, X., Chen, P., Wang, Y. \& Zhang, L. 2009. Chain conformation and rheological behaviour of an extracellular heteropolysaccharide Erwinia gum in aqueous solution. Carbohydrate Resources 344: 113-119.

Nurfatimah Mohd Thani, Siti Mazlina Mustapa Kamal*, Farah Saleena Taip \& Alifdalino Sulaiman

Department of Process and Food Engineering

Faculty of Engineering

Universiti Putra Malaysia

43400 UPM Serdang, Selangor Darul Ehsan

Malaysia

\section{Rozita Omar}

Department of Chemical and Environmental Engineering Faculty of Engineering

Universiti Putra Malaysia

43400 UPM Serdang, Selangor Darul Ehsan

Malaysia

*Corresponding author; email: smazlina@upm.edu.my

Received: 16 November 2020

Accepted: 5 February 2021 